\title{
Pengaruh Tax Amnesty dan Kondisi Keuangan pada Tingkat Kepatuhan Wajib Pajak Orang Pribadi
}

\author{
Putu Vio Narakusuma Ardayani ${ }^{1}$ \\ I Ketut Jati ${ }^{2}$ \\ ${ }^{1,2}$ Fakultas Ekonomi dan Bisnis Universitas Udayana (Unud), Bali, Indonesia \\ e-mail:narakusumavio@gmail.com
}

\begin{abstract}
ABSTRAK
Penelitian ini bertujuan untuk mengetahui pengaruh tax amnesty dan kondisi keuangan pada tingkat kepatuhan wajib pajak orang pribadi yang terdaftar di KPP Pratama Denpasar Timur. Populasi dalam penelitian ini adalah 38.647 wajib pajak orang pribadi yang terdaftar di KPP Pratama Denpasar Timur tahun 2017. Responden penelitian ini adalah 100 wajib pajak orang pribadi yang terdaftar di KPP Pratama Denpasar Timur yang telah mengikuti program tax amnesty. Teknik analisis data yang digunakan adalah analisis regresi linier berganda. Hasil penelitian ini menunjukkan bahwa tax amnesty dan kondisi keuangan berpengaruh positif pada tingkat kepatuhan wajib pajak orang pribadi Hasil penelitian ini diharapkan mampu memberikan referensi, masukan dan tambahan informasi bagi pihakpihak terkait terutama pemerintah (DJP) sehingga di masa mendatang hasil penelitian ini dapat membantu proses pengambilan keputusan dalam rangka meningkatkan tingkat kepatuhan wajib pajak orang pribadi.
\end{abstract}

Kata kunci: Tax amnesty, kondisi keuangan, kepatuhan wajib pajak

\begin{abstract}
This study aims to determine the effect of tax amnesty and financial conditions on the level of individual taxpayer compliance registered at the East Denpasar Primary Tax Office. The population in this study was 38,647 individual taxpayers registered in East Denpasar Primary Tax Office in 2017. The respondents of this study were 100 individual taxpayers registered at the East Denpasar KPP Pratama. The data analysis technique used is multiple linear regression analysis. The results of this study indicate that tax amnesty and financial conditions have a positive effect on the level of individual taxpayer compliance. The results of this study are expected to be able to provide references, input and additional information for relevant parties, especially the government (DGT) so that in the future the results of this study can help decision making process in order to increase the level of individual taxpayer compliance.

Keywords: Tax amnesty, financial condition, taxpayer compliance
\end{abstract}

\section{PENDAHULUAN}

Menurut Undang-Undang tentang Kententuan Umum dan Tata Cara Perpajakan

(UU KUP) pasal 1 ayat (2), wajib pajak merupakan orang pribadi atau badan, meliputi pembayar pajak, pemotong pajak, dan pemungut pajak, yang mempunyai hak dan kewajiban perpajakan sesuai dengan ketentuan peraturan perundangundangan perpajakan. Dengan melihat pengertian tersebut, maka kontribusi yang 
dilakukan oleh para wajib pajak sangat menentukan seberapa luas dan besarnya tingkat pembangunan yang nantinya dapat dilakukan pemerintah Indonesia sebagai wujud untuk meningkatkan kesejahteraan rakyat Indonesia. Mengingat pentingnya kontribusi pajak dalam rangka meningkatkan kesejahteraan rakyat, maka pemerintah terus menggenjot aparatur pajak agar dapat mencapai target penerimaan pajak yang telah ditetapkan.

Berkaitan dengan upaya pemerintah untuk mencapaian target pajak yang telah ditetapkan, tak jarang pula pemerintah mengalami kesulitan terkait dengan proses pemungutan pajak yang disebabkan oleh keengganan wajib pajak dalam memenuhi kewajiban perpajakannya. Menurut Mardiasmo (2014) dalam Wirawan dan Noviari (2017) "Setoran pajak dari kelompok wajib pajak orang pribadi sejauh ini terlalu rendah. Terutama, wajib pajak dari kalangan non karyawan atau memiliki pekerjaan sendiri termasuk usaha profesi”. Hal ini menunjukkan bahwa wajib pajak orang pribadi seperti pengusaha dan profesi belum memenuhi kewajiban pajaknya dengan baik.

Tabel 1.

Tingkat Kepatuhan Pelaporan Wajib Pajak Orang Pribadi di KPP Pratama Denpasar Timur Tahun 2013-2017

\begin{tabular}{lrrrrr}
\hline & & \multicolumn{5}{c}{ Tahun } \\
& 2013 & 2014 & 2015 & \multicolumn{1}{c}{2016} & \multicolumn{1}{l}{2017} \\
\hline 1. WPOP Terdaftar* & 91.440 & 83.926 & 87.652 & 91.084 & 96.073 \\
OP Non Karyawan & 22.018 & 22.196 & 22.196 & 22.605 & 23.788 \\
OP Karyawan & 69.422 & 61.730 & 65.456 & 68.479 & 72.285 \\
& & & & & \\
2. WPOP Terdaftar Wajib SPT & 59.030 & 53.710 & 51.078 & 51.662 & 52.417 \\
OP Non Karyawan & 12.900 & 10.782 & 8.500 & 7.494 & 8.126 \\
OP Karyawan & 46.130 & 42.928 & 42.578 & 44.168 & 44.291 \\
& & & & & \\
3. Realisasi SPT & 36.368 & 35.820 & 36.928 & 41.175 & 38.647 \\
OP Non Karyawan & 3.981 & 4.021 & 4.397 & 5.248 & 5.984 \\
OP Karyawan & 32.387 & 31.799 & 32.531 & 35.927 & 32.663 \\
& & & & & \\
4. Rasio Kepatuhan Pelaporan & $61,61 \%$ & $66,70 \%$ & $72,30 \%$ & $79,70 \%$ & $73,73 \%$ \\
(3:2) & & & & &
\end{tabular}




$\begin{array}{llllll}\text { OP Non Karyawan } & 30,86 \% & 37,29 \% & 51,73 \% & 70,03 \% & 73,64 \% \\ \text { OP Karyawan } & 70,21 \% & 74,08 \% & 76,40 \% & 81,34 \% & 73,75 \%\end{array}$

Sumber: KPP Pratama Denpasar Timur, 2018

Berdasarkan Tabel 1tingkat kepatuhan pelaporan wajib pajak orang pribadi di KPP Pratama Denpasar Timur tahun pada tahun 2013 sampai 2016 baik non karyawan dan karyawan terus mengalami peningkatan dan kemudian pada tahun 2017 tingkat kepatuhan pelaporan wajib pajak orang pribadi sebagai karyawan mengalami penurunan sebanyak 7,59 persen. Pada tahun 2016 tingkat peningkatan kepatuhan wajib pajak paling tinggi sejak lima tahun terakhir dimana peningkatan kepatuhan pelaporan wajib pajak orang pribadi non karyawan sebesar 18,3 persen dan karyawan sebanyak 4,94 persen. Masih belum tercapainya target pajak 2017 mengindikasikan masih ada wajib pajak yang belum patuh.

Dalam rangka menyikapi kesulitan yang dihadapi dalam upaya pencapaian target kepatuhan wajib pajak sekaligus penerimaan pajak, pemerintah telah melakukan berbagai terobosan, salah satunya yaitu dengan melaksanakan program tax amnesty atau pengampunan pajak. Undang-Undang Republik Indonesia No. 11 Tahun 2016 Tentang Pengampunan Pajak, menyebutkan "Pengampunan pajak adalah penghapusan pajak yang seharusnya terutang, tidak dikenai sanksi administrasi dibidang perpajakan dan sanksi pidana dibidang perpajakan, dengan cara mengungkapkan harta dan membayar uang tebusan sebagaimana diatur didalam Undang-undang ini”. Dengan menerapkan kebijakan ini diharapkan dapat meningkatkan subyek pajak maupun obyek pajak. Subyek pajak dapat berupa kembalinya dana-dana yang berada di luar negeri, sedangkan dari sisi obyek pajak berupa penambahan jumlah wajib pajak. Program tax amnesty juga diharapkan 
dapat menigkatkan penerimaan pajak yang selama ini belum atau kurang dibayar. Dengan meningkatnya penerimaan pajak, maka pembangunanpun akan terlaksana dengan optimal (Robbins, 2001).

Pembangunan akan terlaksana dan target penerimaan pajak dapat tercapai jika semua wajib pajak yang ada memiliki kepatuhan dalam membayar pajak. Manurung Romulus (2003) dalam penelitiannya menemukan bahwa sejumlah wajib pajak orang pribadi melaporkan pajak terutangnya secara tidak benar (dalam Ekawati, 2008). Ini mengisyaratkan bahwa walaupun penerimaan pajak mencapai targetnya belum tentu tingkat kepatuhan wajib pajak akan meningkat. Maka dari itu, pemerintah Indonesia melaksanakan program tax amnesty dengan harapan dapat merangsang kenaikan tingkat kepatuhan wajib pajak dan penerimaan pajak di Indonesia(Lussier, 2007).

Menurut Nurani (2016) dalam penelitiannya menyebutkan bahwa program amnesti pajak untuk mengatasi masalah kepatuhan pajak di Surakarta pada tahun 2016 dapat dikatakan telah efektif, walaupun hasilnya belum sampai. Hal ini dapat dibuktikan dengan meningkatnya pelaporan Wajib Pajak kepada STO Surakarta meski perbaikan tersebut belum mencapai target yang diharapkan pada periode ini dengan target kenaikan sebesar 44 persen atau Rp 1,9 triliun rupiah. Peneitian tersebut juga sejalan dengan penelitian yang dilakukan oleh Ariesta dan Latifah (2017) dimana tax amnesty berpengaruh dan berkontribusi sebesar 5,90\% terhadap kepatuhan wajib pajak di KPP Pratama Semarang Candisari. Penelitian yang dilakukan oleh Sari dan Nuswantara (2017) juga menyebutkan bahwa 
variabel persepsi manfaat tax amnesty berpengaruh terhadap kepatuhan wajib pajak.

Ketiga penelitian tersebut tidak sejalan dengan penelitian yang dilakukan oleh Saraçoğlu dan Çaşkurlu (2011) dimana ketika mempertimbangkan frekuensi amnesti pajak di Turki, disimpulkan bahwa amnesti pajak efektif untuk mengarahkan wajib pajak ke operasi yang tidak terdaftar dan mempersulit kepatuhan pajak. Hal tersebut juga didukung oleh penelitian Mutlu dan Taşc1 (2013) yang menyatakan bahwa amnesti pajak dapat menyebabkan warga dengan itikad baik mempertimbangkan bahwa sistem pajak tidak adil dan penghindaran pajak tidak salah, sehingga mereka akan memiliki keberanian untuk tidak patuh akan kewajiban pajak mereka. Junpath et al. (2016) yaitu jika amnesti pajak dipertimbangkan secara berulang, hal itu dapat berdampak negatif terhadap tingkat kepatuhan wajib pajak yang sebelumnya sudah patuh maupun belum patuh.

Kondisi keuangan juga merupakan variabel yang berpotensi memengaruhi kepatuhan wajib pajak (Junpath, 2013). Menurut Torgler (2004) dalam Monica (2013), kualitas pelayanan sebaik apapun tidak menjamin wajib pajak tepat waktu dalam membayar pajak apalagi jika kondisi keuangan wajib pajak dalam keadaan buruk. Namun disisi lain, tidak hanya wajib pajak dengan kondisi keuangan yang buruk yang tidak patuh dalam membayar kewajiban perpajakannya (Koontz, 1990). Hal ini diperkuat oleh penelitian Lee dan Carley (2009) yang menyatakan bahwa wajib pajak yang berpenghasilan tinggi juga diyakini menghindar atau tidak patuh karena adanya tarif pajak progresif yang menyebabkan kewajiban 
perpajakan mereka lebih tinggi dibandingkan dengan wajib pajak yang berpenghasilan rendah (Azhar et al., 2017). Seseorang yang mengalami kesulitan keuangan akan merasa tertekan ketika mereka diharuskan membayar kewajibannya termasuk pajak (Lunenberg, 2011). Menurut penelitian yang dilakukan oleh Aryobimo dan Cahyonowati (2012), kondisi keuangan wajib pajak dan kepatuhan wajib pajak menunjukkan korelasi positif artinya apabila wajib pajak memiliki kondisi keuangan yang baik maka tingkat kepatuhan wajib pajak tinggi. Hal tersebut juga sejalan dengan penelitian yang dilakukan oleh Mory (2015) dimana kondisi keuangan berpengaruh signifikan terhadap kepatuhan wajib pajak orang pribadi yang melakukan kegiatan usaha dan pekerjaan bebas di KPP Pratama Tanjung Balai Karimun.

Penghasilan wajib pajak berkorelasi negatif pada kepatuhan wajib pajak, artinya apabila penghasilan wajib pajak tinggi maka belum tentu tingkat kepatuhan wajib pajak akan tinggi. Bahkan menurut penelitian Nastilova,dkk (2014), dimana ditemukan bahwa persepsi kondisi keuangan tidak berpengaruh signifkan terhadap kepatuhan wajib pajak orang pribadi. Oleh karena itu, kondisi keuangan seseorang berpotensi memengaruhi kemauannya untuk memenuhi kewajiban pajaknya.

Masyarakat mungkin tidak menyukai adanya pajak, bahkan bila pajak tersebut begitu tinggi atau bahkan diluar kemampuan finansial mereka. Menurut Kirchler (1998), pajak sering dianggap mewakili hilangnya kebebasan keuangan pribadi, pengeluaran tanpa pengembalian yang adil, atau dana yang disia-siakan oleh politisi yang tidak efisien (dalam Sussman dan Olivola, 2011). Namun 
dalamrangka penyelenggaraan pemerintahan serta menjaga kepentingan rakyatnya, suatu negara memerlukan dana untuk memenuhi kepentingan kepentingan tersebut. Dana tersebut tentunya diperoleh dari rakyat di negara tersebut melalui suatu sistem pemungutan wajib yang saat ini disebut pajak (B. I. Wirawan dan Ricahrd, 2014:5). Dalam rangka memenuhi unsur keadilan sesuai dengan dasar negara Republik Indonesia yaitu Pancasila sila kelima, maka dibuatlah aturan terkait dengan pajak yang terlebih dahulu disetujui oleh rakyat. Sebagaimana yang tercantum dalam Pasal 23A UUD 1945 bahwa pajak dan pungutan lain yang bersifat memaksa untuk keperluan negara diatur dalam undang - undang, hal ini berarti semua peraturan perpajak harus merujuk pada suatu undang - undang.

Pengampunan Pajak atau tax amnesty dilaksanakan bukan tanpa dasar yang jelas melainkan tetap berpegang teguh pada asas - asas seperti asas kepastian hukum, keadilan, kemanfaatan, dan kepentingan nasional (Stack, 2006). Disamping itu, karena terdapat harta milik warga negara baik di dalam maupun di luar negeri yang belum atau belum seluruhnya dilaporkan dalam Surat Pemberitahuan Tahunan Pajak Penghasilan sehingga akan berdampak pada hasil penerimaan pajak negara dan kepatuhan wajib pajak, maka program tax amnestypun dilaksanakan untuk meningkatkan penerimaan negara, pertumbuhan suatu perekonomian, repatriasi modal, serta kesadaran dan kepatuhan masyarakat dalam pelaksanaan suatu kewajiban perpajakan demi terciptanya stabilitas ekonomi nasional. 
Putu Vio Narakusuma Ardayani dan I Ketut Jati. Pengaruh ...

Undang - Undang Republik Indonesia Nomor 11 Tahun 2016 tentang pengampunan pajak menyebutkan“Pengampunan pajak merupakan penghapusan pajak yang seharusnya terutang, tidak dikenai sanksi administrasi perpajakan dan sanksi pidana dibidang perpajakan, dengan cara mengungkap harta dan membayar uang tebusan sebagaimana diatur dalam Undang - Undang ini”. Bila dikaitkan dengan perpajakan, teori harapan sangat erat kaitannya dengan motivasi dan perilaku wajib pajak dalam memenuhi kewajiban perpajakannya. Dalam kaitannya dengan tax amnesty, teori harapan dapat menggambarkan bagaimana wajib pajak dalam menentukan keputusan mengenai keikutsertaannya dalam program tax amnesty. Keputusan wajib pajak tersebut didasarkan atas 4 asumsi yang dikemukakan oleh Vroom, antara lain: (1) Gambaran perilaku individu adalah hasil dari pilihan yang didasarkan kebutuhan, motivasi, dan pengalaman masa lalu; (2) Perilaku individu adalah hasil dari pilihan sadar yang sudah diperhitungkan sesuai harapan mereka; (3) Perilaku individu merupakan hasil dari keinginan yang timbul karena adanya perbedaan yang lebih menguntungkan dari sesuatu yang akan mereka pilih; dan (4) Individu akan membuat pilihan diantara berbagai alternatif yang dapat mengoptimalkan hasil untuk mereka secara pribadi. Jadi, keputusan wajib pajak untuk ikut atau tidak berpatisipasi dalam program tax amnesty diasumsikan berdasarkan pada kebutuhan, motivasi, pengalaman masa lalu, perhitungan yang sesuai harapan, keinginan yang timbul karena adanya seuatu yang lebih menguntungkan, serta adanya alternatif yang dapat mengoptimalkan hasil untuk mereka secara pribadi. 
Wajib pajak memiliki motivasi atau harapan tersendiri seperti yang disebutkan dalam 4 asumsi teori harapan Vroom dalam menentukan keputusannya untuk mengikuti program tax amnesty. Terlebih lagi, 4 asumsi yang dikemukakan Vroom tersebut menitikberatkan pada satu poin yaitu mengoptimalkan hasil untuk wajib pajak secara pribadi. Apabila program tax amnesty dipercaya sangat menguntungkan oleh wajib pajak yang selama ini selalu tidak patuh dalam melaksanakan kewajiban perpajakannya, maka wajib pajak tersebut akan termotivasi untuk selalu patuh dalam melaksanakan kewajibannya dikemudian hari setelah mengikuti program ini. Hal tersebut berpotensi terjadi karena setelah program tax amnesty, wajib pajak yang tadinya belum menjadi bagian dari sistem administrasi perpajakan akan masuk menjadi bagian dari sistem administrasi perpajakan, sehingga hanya sedikit kemungkinan wajib pajak untuk mengelak dan menghindar dari kewajiban perpajakan. Oleh karena itu, pelaksanaan tax amnesty berpotensi memengaruhi kepatuhan wajib pajak.

Nurani (2016) dalam penelitiannya menyebutkan bahwa program amnesti pajak untuk mengatasi masalah kepatuhan pajak di Surakarta pada tahun 2016 dapat dikatakan telah efektif. Hal ini dapat dibuktikan dengan meningkatnya pelaporan Wajib Pajak kepada STO Surakarta meski perbaikan tersebut belum mencapai target yang diharapkan pada periode ini dengan target kenaikan sebesar 44 persen atau Rp 1,9 triliun rupiah. Peneitian tersebut juga sejalan dengan penelitian yang dilakukan oleh Ariesta dan Latifah (2017) dimana tax amnesty berpengaruh dan berkontribusi sebesar 5,90\% pada kepatuhan wajib pajak di KPP Pratama Semarang Candisari. Penelitian yang dilakukan oleh Sari dan Nuswantara 
Putu Vio Narakusuma Ardayani dan I Ketut Jati. Pengaruh ...

(2017) juga menyebutkan bahwa variabel persepsi manfaat tax amnesty berpengaruh terhadap kepatuhan wajib pajak. Ketiga penelitian itu juga sejalan dengan penelitian yang dilakukan oleh Wirawan dan Noviari (2017), Rorong, dkk (2017), serta Pattinaja dan Silooy (2018) yang menyatakan bahwa tax amnesty berpengaruh positif pada kepatuhan wajib pajak orang pribadi.

Tax amnesty merupakan kesempatan yang baik bagi wajib pajak orang pribadi yang sebelumnya tidak patuh karena kesempatan ini mungkin tidak akan ada lagi dalam waktu yang dekat jika kita berkaca pada tax amnesty yang sempat dilakukan Indonesia pada tahun 1984. Tax amnesty menguntungkan bagi wajib pajak orang pribadi karena tidak ada sanksi administrasi maupun sanksi pidana saat mengikuti program ini sebab semua catatan perpajakan yang dimiliki oleh wajib pajak akan diputihkan atau dengan kata lain tidak ada lagi pajak terutang, sehingga wajib pajak tidak perlu takut untuk melaporkan hartanya di Indonesia. Berdasarkan keuntungan yang didapatkan oleh wajib pajak yang mengikuti tax amnesty, maka tax amnesty diduga dapat meningkatkan kepatuhan wajib pajak orang pribadi karena wajib pajak yang mengikuti program ini akan secara otomatis terdaftar dalam sistem administrasi perpajakan sehingga wajib pajak akan termotivasi melaksanakan kewajiban perpajakan mereka secara sukarela. Atas dasar argumen - argumen ilmiah yang telah dipaparkan, maka hipotesis yang dapat dirumuskan dalam penelitian ini adalah sebagai berikut:

$\mathrm{H}_{1}$ :Tax amnesty berpengaruh positif pada tingkat kepatuhan wajib pajak orang pribadi di KPP Pratama Denpasar Timur.

Kondisi keuangan wajib pajak merupakan suatu kemampuan wajib pajak dalam hal finansial untuk memenuhi berbagai macam kebutuhannya. Menurut 
Agustiantono (2012), apabila individu dapat memenuhi semua kebutuhan tersebut, baik itu kebutuhan primer, sekunder, maupun tersier berdasarkan pendapatan yang dimiliki tanpa bantuan dari pihak luar berupa pinjaman, dapat dikatakan bahwa kondisi keuangan individu tersebut sangat baik. Namun, apabila individu tersebut seringkali melakukan pinjaman dari pihak luar, dapat dikatakan bahwa kondisi keuangan individu tersebut tidak baik.

Kondisi keuangan individu dapat memiliki pengaruh positif atau negatif pada hubungan antara sikap dan perilaku kepatuhannya (Alabede et al., 2011). Menurut penelitian Walsh (2012), studi empiris telah menemukan hasil yang beragam dimana penghasilan wajib pajak yang lebih tinggi dapat menawarkan lebih banyak kesempatan (atau motif) untuk menghindari pajak tetapi penghasilan wajib pajak yang lebih rendah akan mengurangi arus kas dan dapat menimbulkan kesulitan pembayaran dan pengumpulan pajak. Oleh karena itu, pendapatan yang lebih rendah maupun lebih tinggi dapat berdampak negatif pada kepatuhan.

Nurmianti (2014) menyebutkan "Kondisi keuangan individu dapat dijadikan salah satu variabel prediktor yang dapat mempengaruhi ketidakpatuhan wajib pajak dalam memenuhi kewajibannya sesuai dengan undang-undang perpajakan untuk melaporkan pajaknya". Hal tersebut dilihat beradasarkan situasi yang dikemukakan oleh Slemlord, Bradley, dan Siahaan dalam Agustiantono (2012) dimana di dalam perusahaan, profitabilitas perusahaan telah terbukti merupakan salah satu faktor yang mempengaruhi perusahaan dalam mematuhi peraturan perpajakan karena profitabilitas akan menekan perusahaan untuk melaporkan kewajiban perpajakannya. Berkaitan dengan dunia perpajakan, teori harapan 
sangat erat kaitanya dengan motivasi dan perilaku wajib pajak dalam memenuhi kewajiban perpajakannya. Vroom menyebutkab bahwa teori harapan didasakan pada 4 asumsi, yaitu: 1) Gambaran perilaku individu adalah hasil dari pilihan yang didasarkan kebutuhan, motivasi, dan pengalaman masa lalu; (2) Perilaku individu adalah hasil dari pilihan sadar yang sudah diperhitungkan sesuai harapan mereka; (3) Perilaku individu merupakan hasil dari keinginan yang timbul karena adanya perbedaan yang lebih menguntungkan dari ssuatu yang akan mereka pilih; dan (4) Individu akan memmbuat pilihan diantara berbagai alternatif yang dapat mengoptimalkan hasil untuk mereka secara pribadi.

Berdasarkan asumsi-asumsi yang dikemukakan oleh Vroom, asumsi keempat merupakan asumsi yang paling mendekati untuk menggambarkan variabel kondisi keuangan dalam kaitannya dengan kepatuhan wajib pajak. Wajib pajak diasumsuikan akan memenuhi kewajiban perpajakannya berdasarkan alternatif yang dapat mengoptimalkan hasil untuk mereka secara pribadi. Mereka diasumsikan akan dihadapkan pada 2 alternatif pilihan yaitu melaksanakan kewajiban perpajakan dengan cara patuh sesuai jumlah pajak terutangnya, atau dengan cara tidak patuh demi mengecilkan jumlah kewajiban dari yang seharusnya. Dalam hal ini, kondisi keuangan merupakan variabel yang berpotensi menjadi variabel prediktor yang dapat memengaruhi bagaimana perilaku wajib pajak dalam melaksanakan kewajibannya. Hal tersebut dikarenakan besar kecilnya penghasilan wajib pajak berpotensi untuk memengaruhi kepatuhan wajib pajak dalam melaksanakan kewajiban perpajakannya. Seperti yang disebutkan dalam penelitian Walsh (2012), studi empiris telah menemukan hasil yang beragam 
dimana penghasilan wajib pajak yang lebih tinggi dapat menawarkan lebih banyak kesempatan (atau motif) untuk menghindari pajak tetapi penghasilan wajib pajak yang lebih rendah akan mengurangi arus kas dan dapat menimbulkan kesulitan pembayaran dan pengumpulan pajak.

Aryobimo dan Cahyonowati (2012) dalam penelitiannya menyebutkan bahwa kondisi keuangan wajib pajak dan kepatuhan wajib pajak menunjukkan korelasi positif artinya apabila wajib pajak memiliki kondisi keuangan yang baik maka tingkat kepatuhan wajib pajak tinggi. Hal tersebut juga sejalan dengan penelitian yang dilakukan oleh Engida dan Baisa(2014) dimana ditemukan bahwa kepatuhan pajak dipengaruhi oleh kendala keuangan. Kedua penelitian tersebut didukung pula oleh penelitian Mory (2015) dimana kondisi keuangan berpengaruh signifikan terhadap kepatuhan wajib pajak orang pribadi yang melakukan kegiatan usaha dan pekerjaan bebas di KPP Pratama Tanjung Balai Karimun.

Kondisi keuangan sangat berpotensi memengaruhi kepatuhan wajib pajak orang pribadi. Beban keuangan seorang wajib pajak memungkinkan untuk memengaruhi komitmen wajib pajak tersebut dalam menjalankan kewajiban perpajakannya. Bloomqist juga berpendapat bahwa wajib pajak orang pribadi yang mempunyai pendapatan yang terbatas mungkin akan menghindari pembayaran pajak jika kondisi keuangan wajib pajak tersebut buruk karena pengeluaran keluarganya lebih besar dari pendapatannya. Jadi, wajib pajak dengan kondisi keuangan yang buruk diduga memiliki kecenderungan lebih untuk tidak patuh dalam melaksanakan kewajiban perpajakannya dibandingkan dengan wajib pajak dengan kondisi keuangan yang baik. Atas dasar argumen - argumen ilmiah 
yang telah dipaparkan, maka hipotesis yang dapat dirumuskan dalam penelitian ini adalah sebagai berikut:

$\mathrm{H}_{2}$ :Kondisi keuanganberpengaruh positif pada tingkat kepatuhan wajib pajak orang pribadi di KPP Pratama Denpasar Timur.

\section{METODE PENELITIAN}

Penelitian ini dilakukan pada Kantor Pelayanan Pajak Pratama (KPP) Denpasar Timur yang beralamat di Jalan Kapten Tantular Gedung Keuangan Negara II, No. 4, Renon, Denpasar, Bali. Pemilihan lokasi ini untuk memudahkan pengumpulan data serta agar mudah dijangkau peneliti.

Variabel dependen yang digunakan dalam penelitian ini adalah kepatuhan wajib pajak orang pribadi (Y). Variabel independen yang digunakan dalam penelitian ini adalah tax amnesty $\left(\mathrm{X}_{1}\right)$ dan kondisi keuangan $\left(\mathrm{X}_{2}\right)$.

Menurut Junpath (2013), indikator yang digunakan untuk mengukur pengaruh tax amnesty pada kepatuhan wajib pajak yaitu: 1) Kepercayaan terhadap pemerintah. Keyakinan masyarakat terhadap pemerintah akan mendorong kesuksesan dari program tax amnesty. 2) Kepercayaan terhadap administrasi perpajakan. Kredibilitas dan reputasi administrasi perpajakan atas aspek penegakan hukum akan menentukan keberhasilan tax amnesty. 3) Keyakinan bahwa dimasa yang akan datang tidak akan terdapat pengampunan pajak yang sama.Variabel tax amnesty diukur dengan kuisioner yang terdiri atas 5 item pernyataan yang berasal dari penjabaran ketiga indikator dari Junpath (2013). Masing-masing item pernyataan tersebut diukur dengan menggunakan skala 
Likert, yaitu sangat tidak setuju diberi skor 1, tidak setuju diberi skor 2, netral diberi skor 3, setuju diberi skor 4, dan sangat setuju diberi skor 5 .

Untuk mengukur kondisi keuangan wajib pajak wajib pajak digunakan kuisisoner yang terdiri atas 2 item pernyataan(Syamsudin, 2014). Masing-masing item pernyataan tersebut diukur dengan menggunakan skala Likert, yaitu sangat tidak setuju diberi skor 1 , tidak setuju diberi skor 2, netral diberi skor 3, setuju diberi skor 4, dan sangat setuju diberi skor 5 .

Adapun kriteria wajib pajak patuh (sekarang disebut wajib pajak dengan kriteria tertentu) menurut pasal 17 C Undang - Undang Republik Indonesia Nomor 16 Tahun 2009 tentang Ketentuan Umum dan Tata Cara Perpajakan meliputi: 1) Tepat waktu dalam menyampaikan Surat Pemberitahuan; 2) Tidak mempunyai tunggakan pajak untuk semua jenis pajak, kecuali telah memperoleh izin untuk mengangsur atau menunda pembayaran pajak; 3) Laporan keuangan diaudit oleh Akuntan Publik atau lembaga pengawas keuangan pemerintah dengan pendapat Wajar Tanpa Pengecualian selama 3 (tiga) tahun berturut - turut; dan 4) Tidak pernah dijatuhi hukuman karena melakukan tindak pidana di bidang perpajakan berdasarkan putusan pengadilan yang telah mempunyai kekuatan hukum tetap dalam jangka waktu 5 (lima) tahun terakhir.

Untuk mengukur kepatuhan wajib pajak orang pribadi digunakan kuisioner yang terdiri atas 8 item pernyataan (Saepudin, 2012). Masing-masing item pernyataan tersebut diukur dengan menggunakan skala Likert, yaitu sangat tidak setuju diberi skor 1 , tidak setuju diberi skor 2, netral diberi skor 3, setuju diberi skor 4, dan sangat setuju diberi skor 5 . 
Populasi dalam penelitian ini adalah seluruh wajib pajak orang pribadi yang terdaftar di Kantor Pelayanan Pajak Pratama Denpasar Timur tahun 2017 berjumlah 38.647wajib pajak.Dasar pengambilan sampel menggunakan rumus slovin sebagai berikut:

$$
n=\frac{N}{1+N e^{2}}
$$

Keterangan:

$\mathrm{n}=$ ukuran sampel

$\mathrm{N}=$ ukuran populasi

$\mathrm{e}=$ Presentase kelonggaran ketelitian kesalahan pengambilan sampel yang masih bisa ditolerir, $\mathrm{e}=0,1$

Berdasarkan penjelasan rumus solvin diatas, maka ukuran sampel dapat dihitung sebaga berikut:

$n=\frac{38.647}{1+(38.647)(0,1)^{2}}=99,74 ;$ disesuaikan oleh peneliti menjadi 100 responden.

Pengambilan sampel dalam penelitian ini akan dilakukan dengan teknik accidental sampling, yaitu siapa saja yang secara kebetulan bertemu dengan peneliti, memenuhi kriteria untuk menjadi sumber data, serta sesuai dengan konteks penelitian akan digunakan sebagai sampel. Kriteria sampel dalam penelitian ini adalah wajib pajak orang pribadi yang pernah mengikuti tax amnesty.

Teknik analisis yang digunakan dalam penelitian ini adalah analisis regresi linier berganda.Adapun persamaan regresi linier berganda yang ditetapkan adalah sebagai berikut:

$$
\mathrm{Y}=\alpha+\beta_{1} \mathrm{X}_{1}+\beta_{2} \mathrm{X}_{2}+\varepsilon
$$


Keterangan:

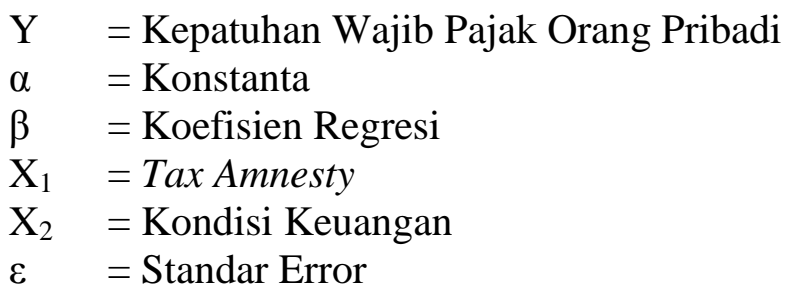

\section{HASIL DAN PEMBAHASAN}

Hasil pengujian instrumen penelitian masing-masing dapat dilihat pada Tabel 2 dan Tabel 3, dimana Tabel 2 menyajikan hasil uji validitas sedangkan Tabel 3 menyajikan hasil uji reliabilitas penelitian ini.

Tabel 2.

Hasil Uji Validitas

\begin{tabular}{|c|c|c|c|c|}
\hline No & Variabel & $\begin{array}{c}\text { Kode } \\
\text { Instrumen }\end{array}$ & $\begin{array}{c}\text { Koefisien } \\
\text { Korelasi }\end{array}$ & Keterangan \\
\hline \multirow[t]{5}{*}{1} & Tax Amnesty $\left(\mathrm{X}_{1}\right)$ & $\mathrm{X} 1.1$ & 0,711 & Valid \\
\hline & & $\mathrm{X} 1.2$ & 0,636 & Valid \\
\hline & & $\mathrm{X} 1.3$ & 0,641 & Valid \\
\hline & & $\mathrm{X} 1.4$ & 0,727 & Valid \\
\hline & & $\mathrm{X} 1.5$ & 0,519 & Valid \\
\hline \multirow[t]{2}{*}{2} & Kondisi Keuangan $\left(\mathrm{X}_{2}\right)$ & $\mathrm{X} 2.1$ & 0,910 & Valid \\
\hline & & $\mathrm{X} 2.2$ & 0,919 & Valid \\
\hline \multirow[t]{8}{*}{4} & Tingkat Kepatuhan Wajib Pajak & Y.1 & 0,704 & Valid \\
\hline & Orang Pribadi (Y) & Y.2 & 0,587 & Valid \\
\hline & & Y.3 & 0,618 & Valid \\
\hline & & Y.4 & 0,614 & Valid \\
\hline & & Y.5 & 0,774 & Valid \\
\hline & & Y.6 & 0,738 & Valid \\
\hline & & Y.7 & 0,659 & Valid \\
\hline & & Y.8 & 0,741 & Valid \\
\hline
\end{tabular}

Sumber: Data diolah, 2018

Berdasarkan Tabel 2 menunjukkan bahwa instrumen penelitian yang terdiri dari item-item pernyataan tax amnesty $\left(\mathrm{X}_{1}\right)$, kondisi keuangan $\left(\mathrm{X}_{2}\right)$, dan tingkat kepatuhan wajib pajak orang pribadi (Y) memiliki nilai koefisien korelasi 
yang lebih besar dari 0,30 . Jadi, seluruh indikator pernyataan tersebut telah memenuhi syarat validitas data.

Tabel 3.

Hasil Uji Reliabilitas

\begin{tabular}{clcc}
\hline No & \multicolumn{1}{c}{ Variabel } & Cronbach's Alpha & Keterangan \\
\hline 1 & Tax Amnesty $\left(\mathrm{X}_{1}\right)$ & 0,639 & Reliabel \\
2 & Kondisi Keuangan $\left(\mathrm{X}_{2}\right)$ & 0,804 & Reliabel \\
3 & Tingkat Kepatuhan Wajib Pajak Orang & 0,832 & Reliabel \\
& Pribadi (Y) & & \\
\hline
\end{tabular}

Sumber: Data diolah, 2018

Berdasasrkan Tabel 3, nilai Cronbach Alpha masing-masing variabel lebih besar dari 0,60. Oleh karena itu, dapat disimpulkan bahwa butir-butir pernyataan dalam kuesioner penelitian ini reliabel dan dapat digunakan.

Analisis statistik deskriptif digunakan untuk menjelaskan deskripsi dari seluruh variabel yang akan dimasukkan dalam model penelitian yang dilihat dari nilai minimum, nilai maksimum nilai rata-rata (mean), dan standar deviasi.Hasil pengujian statistik deskriptif disajikan pada Tabel 4 berikut.

Tabel 4.

Hasil Analisis Statistik Deskriptif

\begin{tabular}{lccccc}
\hline \multicolumn{1}{c}{ Variabel } & N & Min & Max & Mean & Std.Deviation \\
\hline Tax Amnesty (X1) & 100 & 16 & 25 & 19,80 & 2,03008 \\
Kondisi Keuangan (X2) & 100 & 4 & 6 & 5,44 & 0,90252 \\
Tingkat Kepatuhan Wajib Pajak Orang & 100 & 26 & 40 & 34,47 & 3,13164 \\
Pribadi (Y) & & & & & \\
Valid N (listwise) & 100 & & & & \\
\hline Sumber: Data diolah, 2018 & & &
\end{tabular}

Berdasarkan Tabel 4dapat disimpulkan bahwa jumlah pengamatan (N) penelitian ini berjumlah 100. Variabel tax amnesty memiliki nilai minimum sebesar 16 dan nilai maksimum sebesar 25 dengan nilai rata-rata sebesar 19,80 untuk 5 item pernyataan. Nilai rata-rata 19,80 menggambarkan bahwa rata-rata respon responden dalam menjawab pernyataan pada kuesioner cenderung merasa 
setuju pada masing-masing item pernyataan yang berkaitan dengan variabel tax amnesty, artinya WPOP peserta tax amnesty di KPP Pratama Denpasar cenderung merasa percaya bahwa dengan mengikuti tax amnesty mereka akan memperoleh suatu manfaat. Standar deviasi pada variabel ini sebesar 2,03008 yang menunjukkan bahwa standar penyimpangan data terhadap nilai rata-ratanya adalah 2,03008.

Variabel kondisi keuangan memiliki nilai minimum sebesar 4 dan nilai maksimum sebesar 6 dengan nilai rata-rata sebesar 5,44 untuk 2 item pernyataan. Nilai rata-rata sebesar 5,44 mengambarkan bahwarata-rata respon responden dalam menjawab pernyataan pada kuesioner cenderung merasa setuju pada masing-masing item pernyataan yang berkaitan dengan variabel kondisi keuangan, artinya WPOP yang terdaftar di KPP Pratama Denpasar cenderung merasa puas dengan kondisi keuangan mereka.Standar deviasi pada variabel ini sebesar0,90252 yang menunjukkan bahwa standar penyimpangan data terhadap nilai rata-ratanya adalah 0,90252 .

Variabel kepatuhan wajib pajak orang pribadi memiliki nilai minimum sebesar 26 dan nilai maksimum sebesar 40 dengan nilai rata-rata sebesar 34,47. Nilai rata-rata sebesar 34,47 menunjukkan bahwarespon responden dalam menjawab pernyataan pada kuesioner cenderung merasa setuju pada masingmasing item pernyataan yang berkaitan dengan variabel kepatuhan wajib pajak orang pribadi, artinya tingkat kepatuhan WPOP yang terdaftar di KPP Pratama Denpasar cenderung tinggi. Standar deviasi pada variabel ini sebesar 3,13164 yang 
menunjukkan bahwa standar penyimpangan data terhadap nilai rata-ratanya adalah 3,13164 .

Hasil uji asumsi klasik penelitian ini disajikan pada Tabel 5, 6, dan 7 . Tabel 5 menyajikan hasil uji normalitas, Tabel 6 menyajikan hasil uji multikolinearitas, dan Tabel 7 menyajikan hasil uji heteroskedastisitas.

Tabel 5.

Hasil Uji Normalitas

\begin{tabular}{lr}
\hline & Unstandardized Residual \\
\hline $\mathrm{N}$ & 100 \\
Asymp.Sig. (2-tailed) & $0,010^{\mathrm{c}}$ \\
\hline Sumber: Data diolah, 2018
\end{tabular}

Berdasarkan tabel 5, unstandardized residual memiliki nilai Asymp.Sig. (2-tailed) sebesar 0,010 lebih besar dari taraf signifikansi 0,05. Hal ini berarti seluruh data berdistribusi normal.

Tabel 6.

Hasil Uji Multikolinearitas

\begin{tabular}{lccc}
\hline \multicolumn{1}{c}{ Variabel } & \multicolumn{2}{c}{ Collinearity Statistic } & Keterangan \\
& Tolerance & VIF & \\
\hline Tax Amnesty $\left(\mathrm{X}_{1}\right)$ & 0,991 & 1,009 & Bebas Multikolinearitas \\
Kondisi Keuangan $\left(\mathrm{X}_{2}\right)$ & 0,991 & 1,009 & Bebas Multikolinearitas \\
\hline
\end{tabular}

Sumber: Data primer diolah, 2018

Berdasarkan Tabel 6, hasil uji multikolinieritas menunjukkan masingmasing variabel bebas memiliki nilai tolerance lebih besar dari 0,10 dan nilai VIF lebih kecil dari 10. Oleh karena itu, dapat disimpulkan bahwa tidak ada multikolinieritas antarvariabel bebas dalam model regresi.

Tabel 7.

Hasil Uji Heteroskedastisitas

\begin{tabular}{lcc}
\hline \multicolumn{1}{c}{ Variabel } & Sig. & Keterangan \\
\hline Tax Amnesty $\left(\mathrm{X}_{1}\right)$ & 0,667 & Bebas Heteroskedastisitas \\
Kondisi Keuangan $\left(\mathrm{X}_{2}\right)$ & 0,636 & Bebas Heteroskedastisitas \\
\hline Sumber: Data diolah, 2018 & &
\end{tabular}


Berdasarkan Tabel 7, hasil uji heteroskedastisitas menunjukkan bahwa nilai signifikansi masing-masing variabel diatas 0,05 . Jadi, dapat disimpulkan bahwa model regresi dalam penelitian ini bebas dari gejala heteroskedastisitas.

Hasil uji analisis regresi linear berganda disajikan pada Tabel 8.

Tabel 8.

Hasil Uji Analisis Regresi Linear Berganda

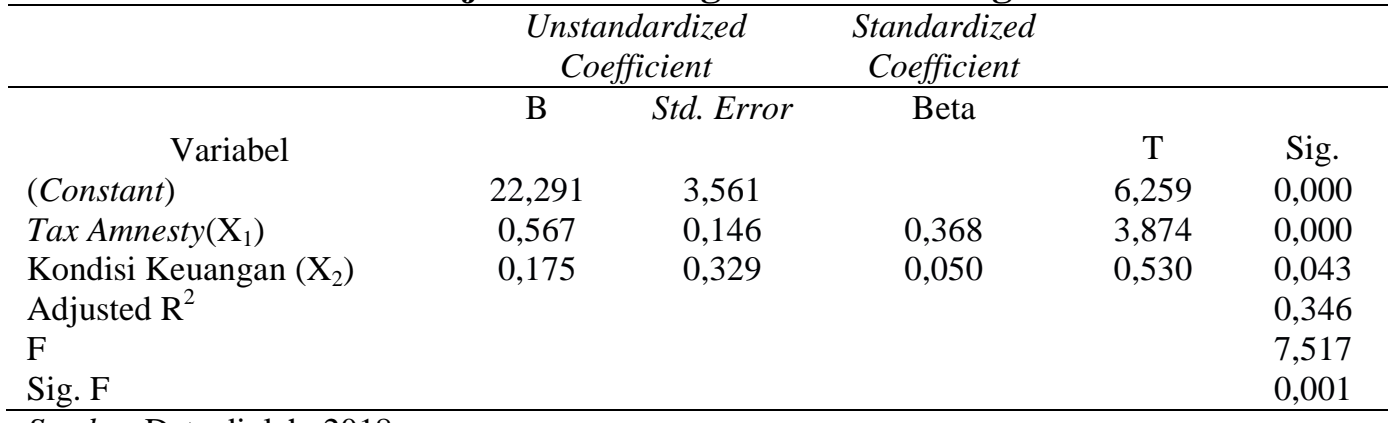

Sumber:Data diolah, 2018

Berdasarkan Tabel 8 persamaan regresi linear berganda yang dapat

disusun sebagai berikut.

$$
Y=22,291+0,567 X_{1}+0,175 X_{2}
$$

Koefisien determinasi dapat dilihat pada output Model Summary dari hasil analisis regresi. Nilai koefisien determinasi adalah antara 0 sampai 1. Nilai koefisien determinasi yang kecil berarti kemampuan variansi variabel independen dalam menjelaskan variansi variabel dependen sangat terbatas, tetapi apabila koefisien determinasi tinggi berarti variabel independen mampu sepenuhnya menjelaskan variansi dari variabel dependen. Berdasarkan nilai Adjusted $\mathrm{R}^{2}$ dapat diketahui berapa persen variansi variabel dependen dapat dijelaskan oleh variansi variabel independen, sedangkan sisanya dipengaruhi atau dijelaskan oleh variansi variabel lain yang tidak dimasukkan dalam model penelitian (Ghozali, 2016:95). 
Berdasarkan Tabel 8 menunjukkan nilai Adjusted $\mathrm{R}^{2}$ sebesar 0,346 yang memiliki arti 34,6\% variansi kepatuhan wajib pajak orang pribadi (Y) dipengaruhi oleh tax amnesty $\left(\mathrm{X}_{1}\right)$, kondisi keuangan $\left(\mathrm{X}_{2}\right)$, sedangkan $65,4 \%$ dipengaruhi oleh faktor-faktor lain yang tidak dimasukkan dalam model penelitian.

Uji F digunakan untuk menguji signifikansi secara serempak seluruh variabel bebas pada variabel terikat. Uji $\mathrm{F}$ dilakukan dengan melihat nilai signifikansi pada tabel ANOVA. Hasil uji F yang signifikan apabila nilai Fsig $\leq$ 0,05 maka hubungan antara variabel-variabel independen adalah signifikan mempengaruhi kepatuhan wajib pajak orang pribadi yang terdaftar di KPP Pratama Denpasar Timur dan model regresi yang digunakan layak uji (Ghozali, 2016:99).

Berdasarkan Tabel 8 menunjukkan bahwa nilai signifikansi $\mathrm{F}$ adalah sebesar 0,001 yang lebih kecil dari 0,05. Hal ini berartivariabel tax amnesty dan kondisi keuangan secara bersama-sama (simultan) berpengaruh pada tingkat kepatuhan wajib pajak orang pribadi dan model dalam penelitian ini layak digunakan $(f i t)$.

Berdasarkan hasil perhitungan yang ditunjukkan pada Tabel 8 variabel tax amnestyberpengaruh positif pada tingkat kepatuhan wajib pajak orang pribadi. Dengan demikian, hipotesis yang menyatakan bahwa tax amnesty berpengaruh positif pada tingkat kepatuhan wajib pajak orang pribadi di KPP Pratama Denpasar Timur diterima. Hal ini berarti, apabila kepercayaan WPOP pada program tax amnesty meningkat maka tingkat kepatuhan WPOP juga akan menigkat, dan begitupun sebaliknya. Hasil penelitian ini mendukung hasil 
penelitian yang dilakukan oleh Wirawan dan Noviari(2017), Rorong, dkk(2017), serta Pattinaja dan Silooy (2018) yang menyatakan bahwa tax amnesty berpengaruh positif pada kepatuhan wajib pajak orang pribadi.

Wajib pajak orang pribadi di KPP Pratama Denpasar Timur percaya bahwa keikutsertaan mereka dalam program tax amnesty akan mendatangkan manfaat bagi mereka. Sebagian besar wajib pajak orang pribadi peserta tax amnesty yang terdaftar di KPP Pratama Denpasar Timur percaya bahwa program tax amnesty adalah kebijakan yang menguntungkan mereka secara financial karena adanya penghapusan pajak yangseharusnya terutang, tidak dikenai sanksi administrasi perpajakan dan juga sanksi pidana di bidang perpajakan, dengan cara mengungkap harta yang belum dilaporkan dan membayar uang tebusan sebagaimana diatur dalam undang-undang. Hal ini tentu akan mendorong wajib pajak untuk patuh dalam melaksanakan kewajiban perpajakannya karena WPOP yang mengikuti program ini percaya pada program tax amnesty yang dilaksanakan oleh pemerintah akan memberikan mereka manfaat yang setimpal dengan kemauan mereka mengikuti tax amnesty. Oleh karena itu tindakan wajib pajak ini sesuai dengan 4 asumsi teori harapan yang dikemukakan oleh Vroom yang menitikberatkan pada satu poin yaitu mengoptimalkan hasil untuk wajib pajak secara pribadi.

Berdasarkan hasil perhitungan yang ditunjukkan pada Tabel 8 variabel kondisi keuangan berpengaruh positif pada tingkat kepatuhan wajib pajak orang pribadi. Dengan demikian, hipotesis yang menyatakan bahwa kondisi keuangan berpengaruh positif pada tingkat kepatuhan wajib pajak orang pribadi di KPP 
Pratama Denpasar Timur diterima. Hal ini berarti, apabila kondisi keuangan wajib pajak orang pribadi meningkat, maka tingkat kepatuhan wajib pajak orang pribadi juga akan meningkat, begitu pula sebaliknya. Hasil penelitian ini mendukung hasil penelitian yang dilakukan oleh Aryobimo dan Cahyonowati (2012), Engida dan Baisa (2014), dan Mory (2015) kondisi keuangan wajib pajak dan kepatuhan wajib pajak menunjukkan korelasi positif artinya apabila wajib pajak memiliki kondisi keuangan yang baik maka tingkat kepatuhan wajib pajak tinggi.

Tingkat kepatuhan pajak yang tinggi dapat terjadi apabila kondisi keuangan wajib pajak dalam keadaan baik sehingga wajib pajak akan merasa terdorong untuk patuh dalam menjalankan kewajiban perpajakannya. Sesuai dengan asumsi keempat teori harapan yang dikemukakan oleh Vroom yaitu individu akan membuat pilihan diantara berbagai alternatif yang dapat mengoptimalkan hasil untuk mereka secara pribadi. Dibandingkan memilih tidak patuh disaat kondisi keuangan mereka dalam keadaan yang baik, wajib pajak lebih baik memilih untuk patuh dalam melaksanakan kewajiban perpajakannya demi menghindari sanksi ketika ada pemeriksaan dikemudian hari.

Hasil penelitian ini diharapkan mampu memberikan referensi, masukan dan tambahan informasi bagi pihak-pihak terkait terutama pemerintah (DJP) yang dirasa perlu untuk memperhatikan tingkat kepatuhan wajib pajak orang pribadi karena variabel tax amnesty dan kondisi keuangan berpengaruh positif pada kepatuhan wajib pajak orang pribadi sehingga di masa mendatang hasil penelitian ini dapat membantu proses pengambilan keputusan dalam rangka meningkatkan tingkat kepatuhan wajib pajak orang pribadi. 
Berdasarkan hasil analisis data dan pembahasan yang telah diuraikan diatas, maka dapat ditarik kesimpulan bahwa Tax amnesty berpengaruh positif pada tingkat kepatuhan wajib pajak orang pribadi di KPP Pratama Denpasar Timur. Hal ini berarti, apabila kepercayaan WPOP pada program tax amnesty meningkat maka tingkat kepatuhan WPOP juga akan menigkat, dan begitupun sebaliknya. Sebagian besar wajib pajak orang pribadi yang terdaftar di KPP Pratama Denpasar Timur percaya bahwa program tax amnesty adalah kebijakan yang bermanfaat. Hal ini tentu akan mendorong wajib pajak untuk patuh dalam menjalankan kewajiban pajaknya setelah mengikuti program tax amnesty karena mereka memiliki kepercayaan pada pemerintah.

Kondisi keuangan berpengaruh positif pada tingkat kepatuhan wajib pajak orang pribadi di KPP Pratama Denpasar Timur. Hal ini berarti, tingkat kepatuhan pajak yang tinggi dapat terjadi apabila kondisi keuangan wajib pajak dalam keadaan yang baik sehingga wajib pajak akan merasa terdorong untuk patuh dalam menjalankan kewajiban perpajakannya.

Berdasarkan hasil penelitian serta simpulan, adapun saran yang dapat diberikan untuk penelitian ini adalah bagi wajib pajak diharapkan untuk selalu patuh dalam melaksanakan kewajiban perpajakannya meskipun program tax amnesty sudah tidak ada lagi karena besarnya tingka penerimaan pajak bergantung pada partisipasi wajib pajak sehingga nantinya negara bisa melaksanakan pembangunan nasional secara merata.Bagi Kantor Pelayanan Pajak (KPP) Pratama Denpasar Timur diharapkan untuk melakukan pengawasan secara berkelanjutan pasca dilaksanakannya tax amnesty sehingga manfaat yang 
diharapkan dari adanya program tax amnesty seperti meningkatnya kepatuhan wajib pajak dan penerimaan pajak benar-benar dapat terealisasi.

\section{REFERENSI}

Abd Al-Mamum, Garrt Entebang, Shazali Aby Mansor, Yasser, Q. R., Thurai Murugan Nathan, \& Rahman, M. A. (2014). The Impact of Demographic Factors on Tax Compliance Attitude and Behaviour in Malaysia. Journal of Finance, Accounting and Management, 5(1), 109-124. https://doi.org/10.1007/s13398-014-0173-7.2

Agustiantono, D. (2012). Analisis Faktor- Faktor yang Mempengaruhi Kepatuhan Wajib Pajak Orang Pribadi: Aplikasi TPB. Studi Empiris WPOP di Kabupaten Pati. Universitas Diponegoro, Semarang.

Alabede, J. O., Ariffin, Z. Z., \& Idris, K. M. (2011). Individual taxpayers ' attitude and compliance behaviour in Nigeria: The moderating role of financial condition and risk preference. Journal of Accounting and Taxation, 3(September), 91-104.

Ariesta, R. P., \& Latifah, L. (2017). Pengaruh Kesadaran Wajib Pajak, Sanksi Perpajakan, Sistem Administrasi Perpajakan Modern, Pengetahuan Korupsi, dan Tax Amnesty terhadap Kepatuhan Wajib Pajak di KPP Pratama Semarang. Jurnal Akuntansi Dewantara, Vol. 1(No. 2), Hal. 173-187.

Aryobimo, P. T., \& Cahyonowati, N. (2012). Pengaruh Persepsi Wajib Pajak tentang Kualitas Pelayanan Fiskus terhadap Kepatuhan Wajib Pajak dengan Kondisi Keuangan Wajib Pajak dan Preferensi Risiko sebagai Variabel Moderating (Studi Empiris terhadap Wajib Pajak Orang Pribadi di Kota Semarang). Diponegoro Journal of Accounting, 1 No. 2, 1-12.

Azhar, M., Radzuan, N., \& Hamid, Z. (2017). Tax arrears amongst individual income taxpayers in Malaysia. Journal of Financial Crime, 24(1), 17-34. https://doi.org/10.1108/JFC-10-2015-0055

Direktorat Jenderal Pajak, K. K. R. I. (2013). Undang-Undang KUP dan Peraturan Pelaksanaannya.

Ekawati, L. (2008). Survei Pemahaman dan Kepatuhan Wajib Pajak Usaha Kecil dan Menengah di Kota Yogyakarta. Teknologi Dan Manajemen Informatika. Vol 6 : Edisi Khusus, 186. 
Engida, T. G., \& Baisa, G. A. (2014). Factors Influencing taxpayers' compliance with the tax system: An empirical study in Mekelle City, Ethiopia. eJournal of Tax Research, 12 No. 2, 433-452.

Ghozali, I. (2016). Statistik Non-Parametrik: Teori dan Aplikasi dengan Program SPSS. Universitas Diponegoro. Semarang.

Junpath, S. 2013. Multiple Tax Amnesties and Compliance in South Africa. South African Journal of Accounting Research.

Monica, N. (2013). Pengaruh Kondisi Keuangan Wajib Pajak Terhadap Hubungan Antara Persepsi Wajib Pajak Tentang Kualitas Pelayanan Fiskus dengan Kepatuhan Wajib Pajak (Studi Empiris terhadap WPOP di Kota Bukittinggi). Jurnal Akuntansi, 1 No. 3.

Mory, S. (2015). Pegaruh Pelayanan Fiskus, Sanksi Perpajakan, Sosialisasi Perpajakan, Kesadaran Wajib Pajak dan Kondisi Keuangan Terhadap Kepatuhan Wajib Pajak (Studi pada Wajib Pajak Orang Pribadi yang Melakukan Kegiatan Usaha dan Pekerjaan Bebas di KPP Pratama Tanjung. Jurnal Akuntansi Fakultas Ekonomi Universitas Maritim Raja Ali Haji.

Nastilova, R., Puspa, D. F., \& Yunilma. (2014). Pengaruh Persepsi Tentang Kondisi Keuangan Wajib Pajak Pribadi dan Kesadaran Pajak Terhadap Kepatuhan Wajib Pajak di Kpp Pratama Padang. E-Jurnal Akuntansi Universitas Bung Hatta, 5 No. 1.

Nurani, D. C. (2016). Program Pengampunan Pajak (Tax Amnesty) Untuk Mengatasi Masalah Kepatuhan Wajib Pajak Di Wilayah Surakarta Tahun 2016. PPKn, 4(2), 947-954.

Pattinaja, E. M., \& Silooy, R. W. (2018). Pengaruh Sunset Policy , Tax Amnesty Dan Kesadaran Wajib Pajak Terhadap Kepatuhan Wajib Pajak (Studi Pada Wajib Pajak Orang Pribadi di KP2KP Masohi). Manis, 2, 25-43.

Presiden Republik Indonesia. Undang-Undang Republik Indonesia No. 11 Tahun 2016 Tentang Pengampunan Pajak (2016). Indoneisa.

Presiden Republik Indonesia. Undang - Undang Nomor 11 Tahun 2016 Tentang Pengampunan Pajak (2016). Indonesia.

Rorong, E. N., Kalangi, L., \& Runtu, T. (2017). Pengaruh Kebijakan Tax Amnesty, Kesadaran Wajib Pajak, dan Sanksi Pajak Terhadap Kepatuhan Wajib Pajak Orang Pribadi di KPP Pratama Manado. Riset Akuntansi Going Concern, 12(2), 175-187. 
Saepudin, A. 2012. Perpajakan Serta Transparansi Dalam Pajak. Jurnal Akuntansi Fakultas Ekonomi Universitas Siliwangi, Hal 1-13.

Saraçoğlu, F., \& Çaşkurlu, E. (2011). Tax Amnesty with Effects and Effecting Aspects: Tax Compliance, Tax Audits and Enforcements Around; The Turkish Case. International Journal of Business and Social Science, 2(7), 95-103.

Sari, R. I., \& Nuswantara, D. A. (2017). The Influence of Tax Amnesty Benefit Perception to Taxpayer Compliance. Jurnal Dinamika Akuntansi, 9(2), 176183.

Sussman, A. B., \& Olivola, C. Y. (2011). Axe the Tax: Taxes Are Disliked More than Equivalent Costs. Journal of Marketing Research, 48(SPL), S91-S101. https://doi.org/10.1509/jmkr.48.SPL.S91

The Republic of Indonesia. (1945). Undang-Undang Dasar Negara Republik Indonesia Tahun 1945. Statute, 1-9. https://doi.org/10.1007/s13398-0140173-7.2

Walsh, K. (2012). Understanding Taxpayer Behaviour - New Opportunities for Tax Administration. The Economic Social Review, 43(3), 451-475.

Wirawan, B. I., \& Ricahrd, B. (2014). Hukum Pajak. Jakarta: Salemba Empat.

Wirawan, I. B. N. A. P., \& Noviari, N. (2017). Pengaruh Penerapan Kebijakan Tax Amnesty dan Sanksi Perpajakan Terhadap Kepatuhan Wajib Pajak Orang Pribadi, 21, 2165-2194. 